\title{
FACTORS WHICH STRATEGICALLY EXPLAIN THE COMPETITIVENESS OF A TOURISM DESTINATION: EVIDENCE FROM SINGAPORE AND SRI LANKA
}

\author{
Fatores que explicam estrategicamente a competitividade de um destino turístico: \\ evidências de Cingapura e Sri Lanka
}

\begin{abstract}
M. Prasad F. Jayasuriya,Cheng Guoping
School of Management, Wuhan University of Technology,

Wuhan, P.R. China, 430070

E-mail: mprasadfj@yahoo.com, chenggp@whut.edu.cn - corresponding author
\end{abstract}

\begin{abstract}
Globally tourism industry has experienced rapid growth in the last 25 years, a trend predicted to continue in future and as such, the field of tourism has emerged as an area of theoretical and practical interest. Although the competition among countries engaged in tourism has increased, the world travel and tourism competitive index (TTCI) reveals striking disparities among developed and developing countries as tourism destinations. This paper is an attempt to examine the elementary reasons for such disparity through identification of competitive factors which strategically explain the position and competitiveness of a tourism destination. For clarity and better understanding the study was conducted with evidence from Singapore and Sri Lanka. Data collection was carried out adopting a survey instrument with purposive sampling and structured questionnaire to examine fifteen factors illustrating tourism destination competitiveness based on responses received from the two countries - 70 from Singapore and 66 from Sri Lanka. The analyzed data were used in a model of strategic evaluation of tourism destination to diagnose the strengths, weaknesses as well as the competitive opportunities of the two countries through the review of 15 competitive factors. The results strategically explained the competitive positions of both tourism destinations, while findings on factors provided guidelines to achieve greaterdestination competitiveness. Further, the modelofstrategic evaluationfirst tested in Spain for tourism destination competitiveness, was extended for pertinence in other tourism destinations and situations.
\end{abstract}

Key words: Developed and developing countries, Competitive factors, Position and competitiveness of a tourism destination, Model of strategic evaluation of tourism destination

Recebido em: 15/12/2016

Aceito em: 31/03/2017 


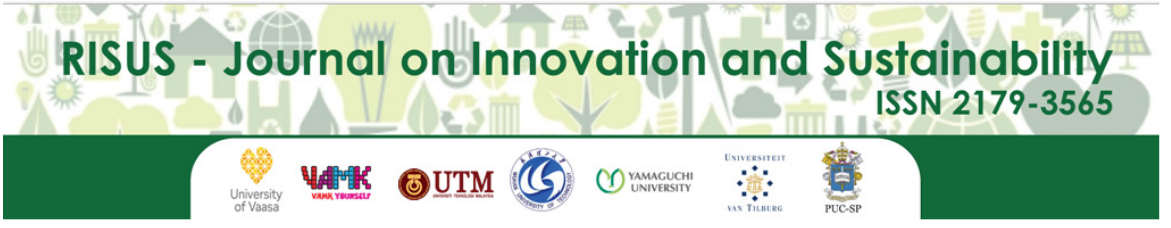

Editor Científico: Arnoldo José de Hoyos Guevara Editora Assistente: Lívia Lopes Aguiar

\title{
FACTORS WHICH STRATEGICALLY EXPLAIN THE COMPETITIVENESS OF A TOURISM DESTINATION: EVIDENCE FROM SINGAPORE AND SRI LANKA
}

\begin{abstract}
Fatores que explicam estrategicamente a competitividade de um destino turístico: evidências de Cingapura e Sri Lanka
\end{abstract}

\begin{abstract}
M. Prasad F. Jayasuriya,Cheng Guoping
School of Management, Wuhan University of Technology,

Wuhan, P.R. China, 430070

E-mail: mprasadfj@yahoo.com, chenggp@whut.edu.cn - corresponding author
\end{abstract}

\begin{abstract}
Resumo: A indústria do turismo mundial tem experimentado um rápido crescimento nos últimos 25 anos, uma tendência que se prevê que continue no futuro e, como tal, o setor do turismo surgiu como uma área de interesse teórico e prático. Embora a concorrência entre os países envolvidos no turismo tenha aumentado, o índice mundial de viagens e turismo (TTCI) revela notáveis disparidades entre os países desenvolvidos e em desenvolvimento como destinos turísticos. Este artigo é uma tentativa de examinar as razões elementares para tal disparidade através da identificação de fatores competitivos que explicam estrategicamente a posição e a competitividade de um determinado destino. Para maior clareza e comprensão, o estudo foi realizado utilizando evidências referentes a Cingapura e Sri Lanka. Acoleta de dados foi realizada com a adoção de um instrumento de pesquisa com amostragem intencional e questionário estruturado para analisar quinze fatores que ilustram a competitividade do destino turístico com base nas respostas recebidas dos dois países - 70 de Cingapura e 66 do Sri Lanka. Os dados analisados foram utilizados em um modelo de avaliação estratégica de destino turístico para diagnosticaros pontos fortes, fracose as oportunidades competitivas destes paises através da revisão de 15 fatores competitivos. Os resultados explicaram estrategicamente as posições competitivas de ambos os destinos turísticos, enquanto as conclusões sobre os fatores forneceram diretrizes para alcançar maior competitividade no destino. Além disso, o modelo de avaliação estratégica testado pela primeira vez em Espanha para a competitividade do destino turístico foi estendido de foram a poder ser utilizado em outros destinos turísticos e situações.
\end{abstract}

Palavras chave: Países desenvolvidos e em desenvolvimento, Fatores competitivos, Posição e competitividade de um destino turístico, Modelo de avaliação estratégica do destino turístico.

Recebido em: 15/12/2016

Aceito em: 31/03/2017 


\section{INTRODUCTION}

While tourism generates a significant amount of foreign exchange earnings that also contribute to the economic growth of developed countries, such ingredient of growth has not been effectively harnessed by most of the developing nations. The world travel and tourism destination rankings of 2015 highlight this fact with developed countries occupying most of the top positions including the top 10 while developing nations are behind in the ranking list of 141 countries (TTCR, 2015).

This leads to the question 'why many developing countries with bio diversity, strong culture, historical artifacts and abundance of natural resources are lagging behind in destination competitiveness?', especially in comparison to developed nations which sometimes have limited natural or inherited resources. The answer to this question exposes the fact that unlike many commercial products, in tourism a destination delivers an "experience" to its visitors and the inherited resources only will no longer create that experience; instead, a destination's competitiveness will be determined by how the inherited resources are effectively integrated through efficient management of the tourism supply chain (Fernando \& Long, 2012).

Rodriguez-Diaz \& Espino-Rodriguez (2008) successfully used a model of strategic evaluation based on internal and relational capabilities to study the factors defining the tourism competitiveness of Gran Canaria in Spain; The two scholars further said, 'Moreover, future research should validate the model in other destinations and circumstances'(p. 379).

The study tested this model of strategic evaluation of tourism destination in a developed and a developing country - Singapore and Sri Lanka respectively. In travel and tourism destination rankings, Singapore is 11th while Sri Lanka occupies the 63rd position; Regionally, Singapore is number one and Sri Lanka is number six out of a total of 15 south-east and southern Asian countries (TTCR, 2015). The objective of the study is to explain the different competitive positions of Singapore and Sri Lanka in tourism by identifying the country strengths and weaknesses in terms of factors defining tourism destination competitiveness.

By testing the validity of the model in two destinations with contrasting economies, the study contributes to expand the existing theoretical knowledge. On the other hand, the findings help the tourism authorities of the two countries to identify the factors that need special focus and attention to make their destinations more competitive, which can guide the shaping of their tourism strategies.

The introduction is followed by literature review in section 2 and research methodology in section 3. Data analysis, results and findings are presented in Section 4, while section 5 is the conclusion. Section 6 discusses study limitations and directions for future research. 


\section{LITERATURE REVIEW}

\section{Tourism destination competitiveness}

The competitiveness of a destination depends on its ability to offer goods and services to outperform other destinations(Dwyer \& Kim, 2003). In tourism industry, according to Dupeyras \& MacCallum (2013, p 14),

"Tourism competitiveness for a destination is about the ability of the place to optimize its attractiveness for residents and non-residents, to deliver quality, innovative, and attractive (e.g. providing good value for money) tourism services to consumers and to gain market shares on the domestic and global market places, while ensuring that the available resources supporting tourism are used efficiently and in a sustainable way".

\section{Tourism supply chain management}

The importance of supply chain management in tourism destination competitiveness is evident from the above definition, as the objective of supply chain management is to maximize profits by increasing competitiveness through reduced costs and increased service levels(Crompton, 2009). In general a supply chain includes all parties who will work together directly or indirectly to ensure customer demand level satisfaction (Chopra \& Meindl, 2013) and supply chain management combines a number of business functions such as logistics, purchasing, operations and distribution (Johnsen, Howard \& Miemczyk, 2014). In tourism, it involves combining and integrating different sectors, firms and stakeholders which includes tourism enterprises like hotels, restaurants, tour operators and transporters, supporting industries in entertainment, sports and shopping as well as both public and private sector destination management organizations (Fernando \& Long, 2012). Therefore, the tourism supply chain management can be described as the ability to efficiently integrate all such sectors and functions to satisfy the tourist needs by meeting their service levels at reduced costs, leading to maximized profits through increased market share.

\section{Destination competitiveness and tourism supply chain management}

In tourism, the competition is not between companies but by supply chains (Christopher 2005) and if the tourism supply chain functions more efficiently and effectively with higher volume of business, the tourism destination will be more competitive (Rodriguez-Diaz \& Espino-Rodriguez, 2008). So the tourism destination competitiveness can also be viewed as how a destination uses its available resources in an innovative way using tourism supply chain management.

\section{Destination competitive models}

Based on this understanding, over the last two decades, many scholars have worked on several destination competitive models on different settings (Khin, Daengbuppha \&Nonsiri, 2014), with almost all the models centered around tourism supply chain with due consideration for other factors which include economic, social and political forces. 
Hassan (2000) suggested a destination competitive model comprising of comparative advantage, demand condition, industry structure and environment commitment indicators, examining the relationships among stakeholders. Heath (2002) established a model emphasizing people as key success drivers and communication and information as vital linkages. Dwyer \& Kim's (2003) integrated model consists of six key elements - inherited resources, created resources, supporting resources, situational conditions, destination management and demand conditions. Demand condition here means traveller motivation comprising tourists' perception, awareness and destination image, in contrast to Hassan (2000), where demand condition is the ability of destination to respond to changing nature of market demand. Fernando \& Long (2012) further developed the Dwyer and Kim (2003) model and proposed a new conceptual model by including innovation perspective and focus.

The model developed by Ritchie \& Crouch (2003), known as Calgary model is based on a destination's comparative advantage through inherited resources and its competitive advantage through created resources; this model links 36 attributes covering core resources and attractors, supporting resources and factors, qualifying and amplifying determinant, destination management, destination policy, planning and development as well as macro and micro environmental forces.

The Travel and Tourism Competitive Index (TTCI) developed and used by World Economic Forum since 2007 is the latest development in this endeavor; Today, the TTCI for global country ranking is based on four broad sub-indexes; enabling environment, policy and enabling conditions, infrastructure and natural and cultural resources; these sub-indexes consists of several pillars which are made up of different variables or attributes (TTCR, 2015).

Rodriguez-Diaz \& Espino-Rodriguez(2008) successfully tested a model of strategic evaluation of tourism destination with factors defining the competitiveness of Spanish tourism destination Gran Canaria; this model in Figure 1 is based on internal and relational capabilities and represents a double entry matrix referring to internal and relational strategic value; the model evaluates key factors defining tourism destination competitiveness with tourism supply chain in the focal point combining other areas like geographical, social and socio-cultural conditions, public administration, policy and infrastructure, outsourcing operations, target market segment as well as other stakeholders of the marketing destination.

\begin{tabular}{|c|c|c|c|c|}
\hline \multicolumn{2}{|c|}{$\begin{array}{l}\text { Relational } \\
\text { /Internal }\end{array}$} & \multicolumn{3}{|c|}{ Internal strategic value } \\
\hline \multirow{3}{*}{ 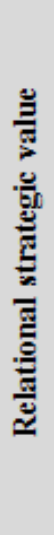 } & ڤ્气 & $\begin{array}{l}\text { C(Weaknesses) } \\
\text { Factors not } \\
\text { generating internal and } \\
\text { relational capabilities }\end{array}$ & $\begin{array}{l}\text { Potential factors to } \\
\text { generate internal } \\
\text { capabilities }\end{array}$ & $\begin{array}{l}\text { High internal value } \\
\text { factors that do not } \\
\text { produce any synergies in } \\
\text { the rest of destination }\end{array}$ \\
\hline & = & $\begin{array}{l}\text { Potential relationships to } \\
\text { generate relational } \\
\text { capabilities }\end{array}$ & $\begin{array}{c}\text { B (Competitive } \\
\text { Opportunities) } \\
\text { Potential factors of core } \\
\text { competence }\end{array}$ & $\begin{array}{c}\text { Factors with high } \\
\text { internal value that } \\
\text { produce a limited synergy } \\
\text { effect }\end{array}$ \\
\hline & 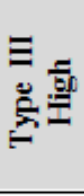 & $\begin{array}{l}\text { Relationships not } \\
\text { exploited to develop } \\
\text { core competence }\end{array}$ & $\begin{array}{l}\text { High potential to } \\
\text { develop core } \\
\text { competence but factors } \\
\text { are not considered } \\
\text { important }\end{array}$ & $\begin{array}{c}\text { A (Strengths) } \\
\text { Factors generating } \\
\text { internal and relational } \\
\text { capabilities; core } \\
\text { competence }\end{array}$ \\
\hline
\end{tabular}

Figure 1 Model of Strategic Evaluation of Tourism Destination adopted from Rodriguez-Diaz \& Espino-Rodriguez (2008) 


\section{RESEARCH METHODOLOGY}

The study utilized quantitative methods, since it involves testing of an existing model for evaluating key factors defining tourism destination competitiveness.

\section{Research context}

The research survey was carried out in Singapore and Sri Lanka - two countries relying on tourism. In 2014, Singapore received approximately 13 million tourists, which accounted for 1.18\% of the global market, while Sri Lanka - comparatively a much bigger country than Singapore had only 1.5 million tourist arrivals. In terms of average nights stayed by a tourist, the ratio of Singapore to Sri Lanka was $1: 2.85$ (Biyagamage \& Jayawardena, 2013), while the average per night expenditure of a tourist in Singapore was 2.35 times the average expenditure of a tourist in Sri Lanka (Data Atlas, 2011-2015).

\section{Measures}

To finalize the factors defining the tourism destination competitiveness of Singapore and Sri Lanka, in depth interviews were conducted with two experts having wider knowledge and experience of the Asian tourism industry. The experts were asked to review the factors used for the destination competitiveness of Gran Canaria (Rodriguez-Diaz \& Espino-Rodriguez, 2008) and suggest any omissions and/or additions with reference to the context of Singapore and Sri Lanka. Based on experts' opinion, all 14 factors used in the original model were retained and one new factor - tourism supply chain innovations (TSC innovations) was added, making it a total of 15 factors.

\section{Data collection tool and methods}

The data collection tool was a structured questionnaire and the same questions used to determine the internal and relational value for tourism destination competitiveness of Gran Canaria (Rodriguez-Diaz \& Espino-Rodriguez, 2008).were employed for this study. The 15 factors identified in section 3.2 were evaluated in each of the six close ended questions using a 7-point Likert-type scale, with 1 as the lowest score and 7 as the highest score. The first four questions examined the internal strategic value (ISV) based on importance, non-substitutability, benefits and contribution for improved competitiveness while the last two questions examined the relational strategic value (RSV) based on integration and sustainability.

The data collection was carried out in Singapore and Sri Lanka during the period January 2016 and May 2016 and purposive sampling method was used to select survey respondents based on their importance to and representation of the tourism industry of the two countries. Out of a total of 200 questionnaires distributed (100 in each country), only 136 were returned - 70 from Singapore and 66 from Sri Lanka and the sector representation of the survey respondents are given in Table 1.

Table 1 Sector Representation of the Questionnaire Respondents

\begin{tabular}{|l|c|c|c|c|c|}
\hline $\begin{array}{l}\text { Sector / } \\
\text { Country }\end{array}$ & $\begin{array}{c}\text { Hotels \& } \\
\text { Accommodation }\end{array}$ & Airlines & $\begin{array}{c}\text { Travel Agents \& } \\
\text { Tour Operators }\end{array}$ & $\begin{array}{c}\text { Tourism } \\
\text { Ministry / Board }\end{array}$ & $\begin{array}{c}\text { Complementary } \\
\text { Offers }\end{array}$ \\
\hline Singapore & 27 & 7 & 17 & 8 & 11 \\
\hline Sri Lanka & 24 & 8 & 16 & 6 & 12 \\
\hline
\end{tabular}




\section{Validity and reliability}

Validity is the accuracy of measures or the extent which truthfully represents a concept (Zikmund, Babin, Carr, \& Griffin, 2010) and by using literature review and expert opinion for identifying the 15 factors used in the study for defining the tourism destination competitiveness of Singapore and Sri Lanka, the authors have ensured the face validity of the data.

Reliability represents the internal consistency or the extent to which the sample patterns of responses to items are consistent or repeatable across items (Helms, 2006) and Cronbach's alpha reliability coefficient was used as the measure to test the reliability, with usual reliability range between 0 and 1 and higher values of Cronbach's alpha meaning good internal consistency of the items in the scale (Gliem \& Gliem, 2003).

The Cronbach's alpha values of ISV and RSV for all 15 factors related to Singapore and Sri Lanka are higher than 0.70 as shown in Table 2, indicating reliability and internal consistency is within the acceptable range (Bryman \& Bell, 2007).

Table 2 Cronbach's Alpha Values of ISV and RSV for the Destination Competitiveness Factors

\begin{tabular}{|c|c|c|c|c|c|}
\hline No & $\begin{array}{c}\text { Factors Defining } \\
\text { Destination Competitiveness }\end{array}$ & $\begin{array}{c}\text { Singapore } \\
\text { Cronbach's } \alpha \\
\text { of ISV }\end{array}$ & $\begin{array}{c}\text { Singapore } \\
\text { Cronbach's } \alpha \\
\text { of RSV }\end{array}$ & $\begin{array}{c}\text { Sri Lanka } \\
\text { Cronbach's } \alpha \\
\text { of ISV }\end{array}$ & $\begin{array}{c}\text { Sri Lanka } \\
\text { Cronbach's } \alpha \\
\text { of RSV }\end{array}$ \\
\hline 1 & Geographical & 0.792 & 0.812 & 0.819 & 0.818 \\
\hline 2 & Environmental & 0.809 & 0.816 & 0.725 & 0.833 \\
\hline 3 & Socio-cultural & 0.794 & 0.834 & 0.716 & 0.834 \\
\hline 4 & Policy & 0.751 & 0.832 & 0.798 & 0.818 \\
\hline 5 & Public administration & 0.803 & 0.799 & 0.826 & 0.822 \\
\hline 6 & Public infrastructure & 0.800 & 0.831 & 0.754 & 0.834 \\
\hline 7 & $\begin{array}{l}\text { Service companies } \\
\text { (outsourcing) }\end{array}$ & 0.740 & 0.807 & 0.795 & 0.835 \\
\hline 8 & Customer segments & 0.819 & 0.817 & 0.828 & 0.832 \\
\hline 9 & Customer performance & 0.755 & 0.835 & 0.785 & 0.803 \\
\hline 10 & Airline companies & 0.767 & 0.770 & 0.816 & 0.809 \\
\hline 11 & $\begin{array}{l}\text { Travel agents and tour } \\
\text { operators }\end{array}$ & 0.810 & 0.839 & 0.788 & 0.771 \\
\hline 12 & $\begin{array}{l}\text { Hotels and non-hotel } \\
\text { accommodation }\end{array}$ & 0.738 & 0.830 & 0.768 & 0.827 \\
\hline 13 & Complementary offers & 0.788 & 0.825 & 0.793 & 0.833 \\
\hline 14 & Direct sales & 0.793 & 0.832 & 0.777 & 0.811 \\
\hline 15 & TSC innovations & 0.810 & 0.816 & 0.821 & 0.819 \\
\hline
\end{tabular}

\section{DATA ANALYSIS, RESULTS AND FINDINGS}

To facilitate the use of the strategic evaluation model, the average values for the 15 factors were calculated under each of the 6 questions from the collected data. Then the internal strategic value (ISV) for each factor was determined by calculating the relevant mean value of question numbers 1 to 4 , which addressed the factors in terms of importance(Q1), non-substitutability(Q2), benefits $(\mathrm{Q} 3)$ and contribution for improved competitiveness(Q4). Similarly, relational strategic value (RSV) for each factor was determined by calculating the mean from question numbers 5 and 6, covering integration(Q5) and sustainability(Q6).

SPSS 22 was used for data analysis and Table 3 and Table 4 display the results of mean values and standard deviations (SD) related to each of the 15 factors with reference to Singapore and Sri Lanka respectively. 
Table 3 Mean \& SD values of ISV and RSV for the Destination Competitiveness Factors in Singapore

\begin{tabular}{|c|l|c|c|c|c|c|c|c|c|c|c|}
\hline No & $\begin{array}{c}\text { Factors Defining } \\
\text { Destination } \\
\text { Competitiveness }\end{array}$ & Q1 & Q2 & Q3 & Q4 & Q5 & Q6 & $\begin{array}{c}\text { ISV } \\
\text { Mean }\end{array}$ & $\begin{array}{c}\text { ISV } \\
\text { SD }\end{array}$ & $\begin{array}{c}\text { RSV } \\
\text { Mean }\end{array}$ & $\begin{array}{c}\text { RSV } \\
\text { SD }\end{array}$ \\
\hline $\mathbf{1}$ & Geographical & 3.27 & 3.43 & 3.60 & 3.91 & 5.26 & 5.66 & 3.55 & 0.48 & 5.46 & 0.28 \\
\hline $\mathbf{2}$ & Environmental & 5.40 & 5.39 & 5.46 & 5.77 & 5.40 & 5.74 & 5.50 & 0.31 & 5.57 & 0.24 \\
\hline $\mathbf{3}$ & Socio-cultural & 3.57 & 3.87 & 3.44 & 3.24 & 3.74 & 3.83 & 3.53 & 0.46 & 3.79 & 0.06 \\
\hline $\mathbf{4}$ & Policy & 5.27 & 4.01 & 4.70 & 4.69 & 4.14 & 4.26 & 4.67 & 0.89 & 4.20 & 0.08 \\
\hline $\mathbf{5}$ & Public administration & 5.09 & 5.31 & 4.87 & 5.33 & 4.97 & 5.56 & 5.15 & 0.37 & 5.26 & 0.41 \\
\hline $\mathbf{6}$ & Public infrastructure & 6.04 & 5.54 & 6.00 & 5.96 & 5.34 & 5.47 & 5.89 & 0.40 & 5.41 & 0.09 \\
\hline $\mathbf{7}$ & $\begin{array}{l}\text { Service companies } \\
\text { (outsourcing) }\end{array}$ & 4.89 & 3.96 & 4.87 & 5.33 & 4.74 & 4.27 & 4.76 & 1.00 & 4.51 & 0.33 \\
\hline $\mathbf{8}$ & Customer segments & 4.31 & 4.17 & 4.46 & 4.24 & 4.21 & 4.54 & 4.30 & 0.21 & 4.38 & 0.23 \\
\hline $\mathbf{9}$ & Customer performance & 5.10 & 4.01 & 4.99 & 4.76 & 4.96 & 5.03 & 4.71 & 0.85 & 4.99 & 0.05 \\
\hline $\mathbf{1 0}$ & Airline companies & 5.87 & 5.90 & 5.86 & 5.03 & 5.50 & 4.51 & 5.66 & 0.73 & 5.01 & 0.70 \\
\hline $\mathbf{1 1}$ & $\begin{array}{l}\text { Travel agents and tour } \\
\text { operators }\end{array}$ & 5.27 & 5.13 & 5.50 & 5.14 & 5.27 & 5.26 & 5.26 & 0.30 & 5.26 & 0.01 \\
\hline $\mathbf{1 2}$ & $\begin{array}{l}\text { Hotels and non-hotel } \\
\text { accommodation }\end{array}$ & 4.77 & 4.37 & 5.09 & 3.71 & 4.49 & 4.34 & 4.49 & 1.02 & 4.41 & 0.10 \\
\hline $\mathbf{1 3}$ & Complementary offers & 5.60 & 4.94 & 5.40 & 5.54 & 5.24 & 5.46 & 5.37 & 0.52 & 5.35 & 0.15 \\
\hline $\mathbf{1 4}$ & Direct sales & 4.54 & 4.63 & 4.34 & 4.01 & 5.06 & 5.17 & 4.38 & 0.47 & 5.11 & 0.08 \\
\hline $\mathbf{1 5}$ & TSC innovations & 5.61 & 5.80 & 5.37 & 5.61 & 5.36 & 5.01 & 5.60 & 0.30 & 5.19 & 0.24 \\
\hline
\end{tabular}

Table 4 Mean \& SD values of ISV and RSV for the Destination Competitiveness Factors in Sri Lanka

\begin{tabular}{|c|l|c|c|c|c|c|c|c|c|c|c|}
\hline No & \multicolumn{1}{|c|}{$\begin{array}{c}\text { Factors Defining } \\
\text { Destination } \\
\text { Competitiveness }\end{array}$} & Q1 & Q2 & Q3 & Q4 & Q5 & Q6 & $\begin{array}{c}\text { ISV } \\
\text { Mean }\end{array}$ & $\begin{array}{c}\text { ISV } \\
\text { SD }\end{array}$ & $\begin{array}{c}\text { RSV } \\
\text { Mean }\end{array}$ & $\begin{array}{c}\text { RSV } \\
\text { SD }\end{array}$ \\
\hline $\mathbf{1}$ & Geographical & 3.27 & 3.43 & 3.60 & 3.91 & 5.26 & 5.66 & 3.55 & 0.48 & 5.46 & 0.28 \\
\hline $\mathbf{2}$ & Environmental & 5.40 & 5.39 & 5.46 & 5.77 & 5.40 & 5.74 & 5.50 & 0.31 & 5.57 & 0.24 \\
\hline $\mathbf{3}$ & Socio-cultural & 3.57 & 3.87 & 3.44 & 3.24 & 3.74 & 3.83 & 3.53 & 0.46 & 3.79 & 0.06 \\
\hline $\mathbf{4}$ & Policy & 5.27 & 4.01 & 4.70 & 4.69 & 4.14 & 4.26 & 4.67 & 0.89 & 4.20 & 0.08 \\
\hline $\mathbf{5}$ & Public administration & 5.09 & 5.31 & 4.87 & 5.33 & 4.97 & 5.56 & 5.15 & 0.37 & 5.26 & 0.41 \\
\hline $\mathbf{6}$ & Public infrastructure & 6.04 & 5.54 & 6.00 & 5.96 & 5.34 & 5.47 & 5.89 & 0.40 & 5.41 & 0.09 \\
\hline $\mathbf{7}$ & $\begin{array}{l}\text { Service companies } \\
\text { outsourcing) }\end{array}$ & 4.89 & 3.96 & 4.87 & 5.33 & 4.74 & 4.27 & 4.76 & 1.00 & 4.51 & 0.33 \\
\hline $\mathbf{8}$ & Customer segments & 4.31 & 4.17 & 4.46 & 4.24 & 4.21 & 4.54 & 4.30 & 0.21 & 4.38 & 0.23 \\
\hline $\mathbf{9}$ & Customer performance & 5.10 & 4.01 & 4.99 & 4.76 & 4.96 & 5.03 & 4.71 & 0.85 & 4.99 & 0.05 \\
\hline $\mathbf{1 0}$ & Airline companies & 5.87 & 5.90 & 5.86 & 5.03 & 5.50 & 4.51 & 5.66 & 0.73 & 5.01 & 0.70 \\
\hline $\mathbf{1 1}$ & $\begin{array}{l}\text { Travel agents and tour } \\
\text { operators }\end{array}$ & 5.27 & 5.13 & 5.50 & 5.14 & 5.27 & 5.26 & 5.26 & 0.30 & 5.26 & 0.01 \\
\hline $\mathbf{1 2}$ & $\begin{array}{l}\text { Hotels and non-hotel } \\
\text { accommodation }\end{array}$ & 4.77 & 4.37 & 5.09 & 3.71 & 4.49 & 4.34 & 4.49 & 1.02 & 4.41 & 0.10 \\
\hline $\mathbf{1 3}$ & Complementary offers & 5.60 & 4.94 & 5.40 & 5.54 & 5.24 & 5.46 & 5.37 & 0.52 & 5.35 & 0.15 \\
\hline $\mathbf{1 4}$ & Direct sales & 4.54 & 4.63 & 4.34 & 4.01 & 5.06 & 5.17 & 4.38 & 0.47 & 5.11 & 0.08 \\
\hline $\mathbf{1 5}$ & TSC innovations & 5.61 & 5.80 & 5.37 & 5.61 & 5.36 & 5.01 & 5.60 & 0.30 & 5.19 & 0.24 \\
\hline
\end{tabular}

With the objective of dividing the survey data into as many boxes as in the model of strategic e valuation of tourism destination, percentile calculations were used to identify the values 3 and 5 to separate the data range of 1 to 7 into three groups. Then the calculated means of ISV and RSV for the 15 factors were used in the model to strategically evaluate their competitive positions in defining the tourism competitiveness of Singapore and Sri Lanka. (Refer Figure 2) 
The strategic analysis of Figure 2 shows that Singapore is positioned on the main diagonal in strong equilibrium having seven factors in box A as strengths, six in box B as competitive opportunities and only two off the diagonal; In contrast, Sri Lanka is in imbalanced position on the diagonal with no strengths and having three factors as unexploited opportunities in box B, eight as weaknesses in box $\mathrm{C}$ while four are off the diagonal. Therefore these results from the model of strategic evaluation of tourism destination provides sound explanation as to why Singapore is a top performing and high ranked tourism destination in comparison to Sri Lanka.
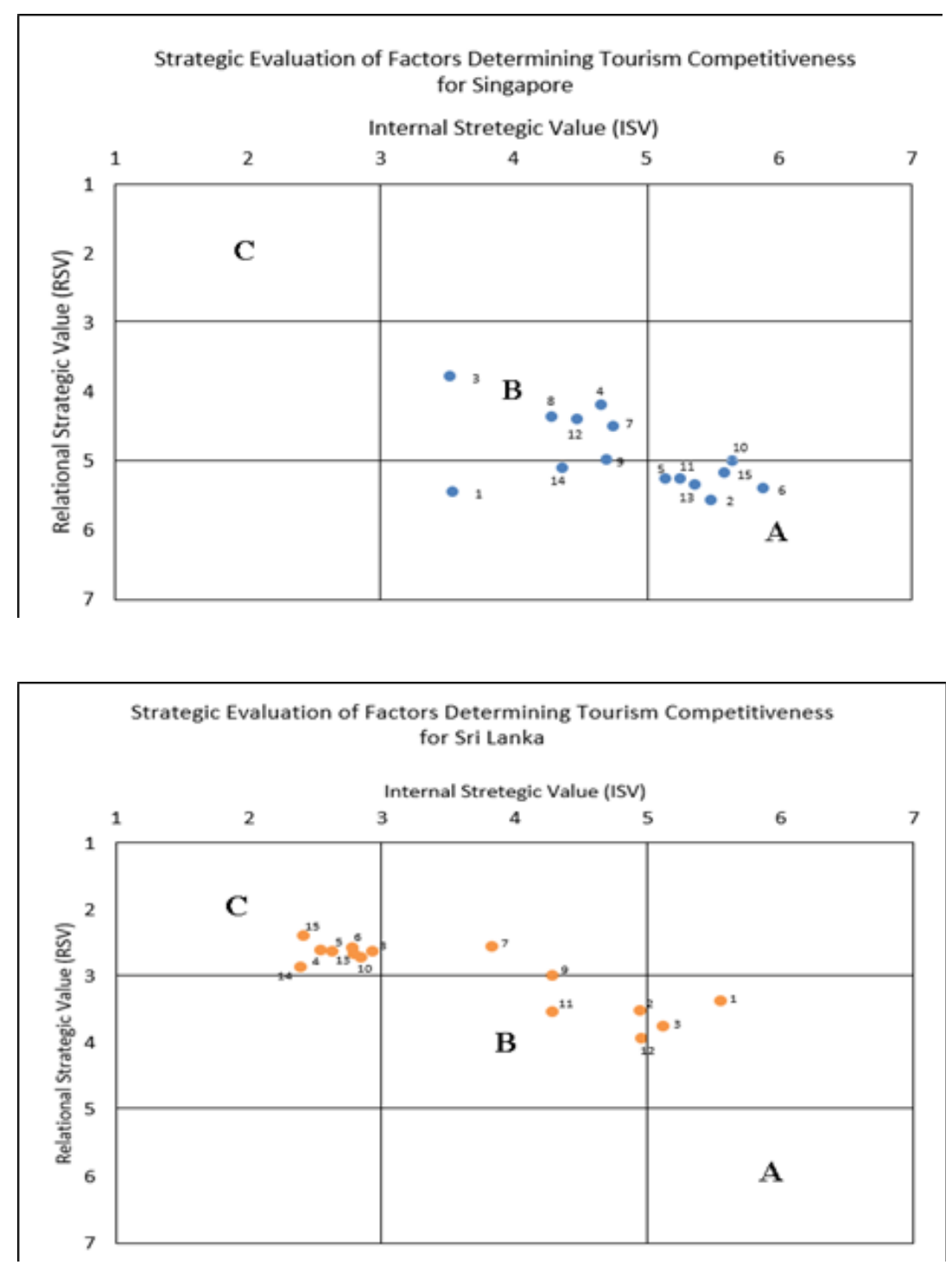

Figure 2 Strategic Evaluation of the 15 Factors Defining the Tourism Destination Competitiveness of Singapore and Sri Lanka 
For further discussion and comparison, the strategic evaluation results of the 15 factors related to Singapore and Sri Lanka are summarized in Table 5.

In Table 5, the seven factors shown in box A are the core competence of destination for Singapore and the tourism authorities should continuously reinforce these strengths to ensure that they do not lose the internal and strategic value of these factors. The six factors in box B have medium strategic values representing competitive opportunities and indicating unrealized potential. Strategically identifying the right factors in box B to pursue as strengths and developing actions to move them should be considered a priority. From the two factors outside the diagonal, direct sales could potentially be moved to a position of core competence with a focused strategy aimed at improving internal vision and generating synergies. Due to its limited natural resources, Singapore possibly may not be considering geographical factor as an internal strength, but has compensated for it with high relational value, which probably explains the off diagonal position of this factor.

Table 5 Summary of Destination Competitiveness Factor Comparison between Singapore and Sri Lanka

\begin{tabular}{|c|c|c|}
\hline Description & Singapore & Sri Lanka \\
\hline $\begin{array}{l}\text { Factors in Box A } \\
\text { Strengths leading } \\
\text { to core } \\
\text { competence }\end{array}$ & $\begin{array}{l}\text { Environmental, Public administration, } \\
\text { Public infrastructure, Airline companies, } \\
\text { Travel agents and tour operators, } \\
\text { Complementary offers, Tourism supply } \\
\text { chain innovations (Total of } 7 \text { Factors) }\end{array}$ & \\
\hline $\begin{array}{l}\text { Factors in Box B } \\
\text { Competitive } \\
\text { Opportunities }\end{array}$ & $\begin{array}{l}\text { Socio-cultural, Policy, Service companies } \\
\text { (outsourcing), Customer segments, } \\
\text { Customer performance, Hotels and non- } \\
\text { hotel accommodation (Total of } 6 \text { Factors) }\end{array}$ & $\begin{array}{l}\text { Environmental, Travel agents and tour } \\
\text { operators, Hotels and non-hotel } \\
\text { accommodation. (Total of } 3 \text { Factors) }\end{array}$ \\
\hline $\begin{array}{l}\text { Factors in Box C } \\
\text { Weaknesses }\end{array}$ & & $\begin{array}{l}\text { Policy, Public administration, Public } \\
\text { infrastructure, Customer segments, } \\
\text { Airline companies, Complementary } \\
\text { offers, Direct sales, Tourism supply chain } \\
\text { innovations. (Total of } 8 \text { Factors) }\end{array}$ \\
\hline $\begin{array}{l}\text { Factors off and } \\
\text { above the diagonal }\end{array}$ & & $\begin{array}{l}\begin{array}{l}\text { Geographical, } \\
\text { companies }\end{array} \text { (outsourcing), Customer } \\
\text { performance. (Total of } \mathbf{4} \text { Factors) }\end{array}$ \\
\hline $\begin{array}{c}\text { Factors off and } \\
\text { below the diagonal }\end{array}$ & $\begin{array}{l}\text { Geographical, Direct sales (Total of } \mathbf{2} \\
\text { Factors) }\end{array}$ & \\
\hline
\end{tabular}


The lack of factors in box A indicates a relative weak position in destination competitiveness for Sri Lanka. The tourism authorities in the country should first concentrate on the three competitive opportunity factors in box B with stable plans to reposition them as core competence of the destination. Having as many as eight factors in box $\mathrm{C}$ as weaknesses and four others outside the diagonal suggest the need for a clear strategic direction for the tourism industry in Sri Lanka. Such direction should provide strategic actions and single out three to four factors to recalibrate as destination strengths while converting most of the remaining factors to a position of medium strategic value in box B. Identification of right factors should be done with the view that factors defining competitiveness in tourism may vary depending on the destination and targeted market segments (Enright \& Newton, 2005). Further, the high IRV's of geographical and socio-cultural factors in comparison to RSV's explain the country dependency on natural and cultural resources for competitive advantage.

The comparison of RSV's show that Singapore has ten factors with high value and five with medium value while Sri Lanka has just the opposite, with five factors of medium value and ten factors of low value. This indicates a very strong comparative position of Singapore in terms of relational capabilities covering integration and sustainability of the tourism supply chain. This position of strength is evident through the competitiveness factor 'tourism supply chain innovations' - where Singapore has it as a strength in box A while for Sri Lanka it is in the weak zone of box C.

\section{CONCLUSION}

The empirical study of the factors defining the tourism destination competitiveness of Singapore and Sri Lanka shows that the model of strategic evaluation of tourism destination produces results which represent and explain the competitive reality of the two destinations. Hence the study contributes to the existing theory by extending the applicability of the model not only to a different region, but also to two different economies - one developed and the other developing.

The model also evaluated the factors based on internal and relational strategic values, which clearly identified the strengths, weaknesses and competitive opportunities for each destination which can guide the relevant tourism authorities of the two countries to take specific steps to improve their country competitive positions.

Finally, the successful application of the model for comparative analysis of two competitor destinations with different economic conditions helps to identify the fundamental lines of action to achieve greater competitiveness in tourism, which can be of more importance and value especially for countries with emerging economies.

\section{FUTURE RESEARCH}

The study was conducted with data collected from higher level respondents identified through purposive sampling, concentrating on strategic level factors defining the tourism destination competitiveness. This can be viewed as a limitation, since the findings may lack the operational level applicability to achieve tourism destination competitiveness. 
The future researchers can conduct a detailed study using the same model to evaluate operational attributes relevant to each of the strategic competitive factors and by involving wider cross section of respondents representing various operational levels of the tourism industry. Alternatively, this study can be extended to combine the operational attributes related to strategic factors which were identified as areas for more focus and special attention in Singapore and Sri Lanka. It will be also interesting to see how the model functions and performs in comparison studies between two developed nations as well as two developing nations, which can lead to some new insights. Further, the knowledge of this research can be extended to study the tourism competitive strategy of a destination.

Finally, tourism supply chain management and tourism supply chain innovations which showed a marked difference between Singapore and Sri Lanka opens up a completely new research area to explore in tourism and destination competitiveness studies. 


\section{REFERENCES}

[1] TTCR - The Travel and Tourism Competitive Report: Growth Through Shocks[M]. World Economic Forum, Geneva, 2015

[2] Fernando, Imali N., \& Long, Wei. New Conceptual Model on Cluster Competitiveness: A New Paradigm for Tourism?[J]. International Journal of Business \& Management, 2012, 7(9):75-84

[3] Rodriguez-Diaz, Manual, \& Espino-Rodriguez, Thomas F. A Model of Strategic Evaluation of a Tourist Destination Based on Internal and Relational Capabilities[J]. Journal of Travel Research, 2008, 46(4): 368-380

[4] Dwyer, L., \& Kim, C. Destination Competitiveness: Determinants and Indicators[J]. Current Issues in Tourism, 2003, 6(5): 369-414

[5] Dupeyras, A., \& MacCallum, N. Indicators for Measuring Competitiveness in Tourism: A Guidance Document[M]. OECD Publishing, OECD Tourism Papers 2013/02

[6] Crompton, R. Supply Chain Management[M]. Chartered Institute of Logistics and Transport Level 5 unit. Huddersfield: The University of Huddersfield, 2009

[7] Chopra, S. \& Meindl, P. Supply Chain Management: Strategy, Planning, and Operation, 5th Edition[M]. London: Pearson, 2013

[8] Johnsen, T. E., Howard, M., \& Miemczyk, J. Purchasing and Supply Chain Management: A Sustainability Perspective[M]. London: Routledge, 2014

[9] Christopher, M. Logistics and Supply Chain Management: Creating Value-added Networks. 3rd ed.[M]. London: Pearson Education, 2005

[10] Khin, EiEi, Daengbuppha, Jaruwan, \& Nonsiri, Petchsri. Destination Competitiveness: A Structural Model For Measuring Attributes Competitiveness of Bagan, Myanmar[J]. International Journal of Business, Economics and Law, 2014, 4(2):51-59

[11] Hassan, S. S. Determinants of Market Competitiveness in an Environmentally Sustainable Tourism Industry[J]. Journal of Travel Research, 2000, 38(3): 239-245

[12] Heath, E. Towards a Model to Enhance Destination Competitiveness; A Southern African Perspective[M]. Unpublished, 2002

[13] Ritchie, J. R. B. \& Crouch, G. I. The Competitive Destination: A Sustainable Tourism Perspective[M]. CABI Publishing, Wallingford, UK, 2003 
[14] Biyagamage, H., \& Jayawardena, C. C. Balancing for the Future Success of Tourism in Sri Lanka[J]. Worldwide Hospitality and Tourism Themes, 2013, 5(5): 505-511

[15] Data Atlas (2011-2015), Knoema[M]. Retrieved May 27, 2016, from Knoema Website: https://knoema.com

[16] Zikmund, William G., Babin, Barry J., Carr, Jon C., \& Griffin, Mitch. Business Research Methods[M]. Mason, Ohio: South Western Cengage Learning, 2010

[17] Helms, J. E.. Treating Cronbach's Alpha Reliability Coefficients as Data in Counseling Research[J]. The Counseling Psychologist, 2006, 34(5), 630-660

[18] Gliem, Joseph A., \& Gliem, Rosemary R. Calculating, Interpreting, and Reporting Cronbach's Alpha Reliability Coefficient for Likert-Type Scales[M]. Presented at the Midwest Research-to-Practice Conference in Adult, Continuing, and Community Education, The Ohio State University, Columbus, OH, October 8-10, 2003

[19] Bryman, A. \& Bell, E. Business Research Methods[M]. Oxford University Press, 2007

[20] Enright, M.J. \& Newton, J. Determinants of Tourism Destination Competitiveness in Asia Pacific: Comprehensiveness and Universality[J]. Journal of Travel Research, 2005, 43: 339-350 